\title{
Self-Esteem And Celebrity Worship In Social Network Bollywood Mania Club Indonesia Members In Jakarta
}

\author{
Novendawati Wahyu Sitasari ${ }^{1}$, Yuli Azmi Rozali ${ }^{2}$, Andini Dwi Arumsari ${ }^{3}$, Dedi Setyawan ${ }^{4}$ \\ \{novenda@esaunggul.ac.id ${ }^{1}$, yuli.azmi@esaunggul.ac.id ${ }^{2}$, andini.dwi@ narotama.ac.id ${ }^{3}$, \\ dedi.unnar@gmail.com $\left.{ }^{4}\right\}$
}

Esa Unggul University ${ }^{1,2}$, Narotama University ${ }^{3}$, Dr. Soetomo University ${ }^{4}$

\begin{abstract}
The purpose of this study was to determine the relationship of self-esteem with celebrity worship on members of social network Bollywood Mania Club Indonesia (BMCI). Use of the Internet results in such groups transcending national and geographical boundaries communities. Hence sustained celebrity worship within outside microcommunities might not be as prevalent in the next generation of middle-aged consumers. Population and sample in this study are members of BMCI in Jakarta, which amounted to 250 people. The sampling technique used in this study is the probability sampling. This research is a correlational-quantitative with Pearson product moment correlation test. Results showed there are relationships between self-esteem with celebrity worship in BMCI members in Jakarta, where the significance value of $0.000(\mathrm{p}>0.05)$. This means that self-esteem affects celebrity worship BMCI members of Bollywood. The relationship is in a negative direction. When members of BMCI has high self-esteem, they will be able to control their emotions, able to evaluate so they would be able to love their idol naturally or it can be said that these individuals are experiencing low celebrity worship. Moreover, when members of BMCI has low self-esteem, when they experience problems, they were less able to control their emotions, he less able to evaluate the situation or problems on themselves, so it tend to seek comfort outside the family by loving their idol excessive or unreasonable, in other words, the individual is experiencing a high celebrity worship.
\end{abstract}

Keywords: Self-esteem, celebrity worship, Bollywood worship

\section{Introduction}

The idolized phenomenon is widely spread in Indonesia; in very alarming level [1]. People who have been idolized are an artist, singers, political figures, and so on. Among those are Bollywood artists. People who idolized artist usually called as fans. Indonesian Bollywood fans eventually form a group called Bollywood Mania Club Indonesia (BMCI). BMCI has 30000 members. Moreover, from Jakarta, there are 5000 members. Those members came from various ages, from kids to adults. This club is formed due to the same love and idolized for Bollywood artist. The love for an idolized person is usually called as celebrity worship.

Celebrity worship is a form of para social relationship which a person becomes obsessed with celebrity [2], [3]. The parasocial relationship is an imaginary relationship from the fans that idolized figure, which is one-way, from the fans to the idol. Celebrity worship is divided into three levels: entertainment social value, the motivation underlying active search of the celebrity fans, intense personal feeling, a feeling of intense reflection and compulsive towards 
celebrities, and borderline pathological tendencies, attitudes such as willingness to do anything for celebrities [4].

Based on an interview with one of BMCI coordinator's in Jakarta, claimed that there are some members of has joined BMCI joined, not only because of their love for the idol's, but also they gain acknowledgment, feels accepted because of the same hobby, and proud due the feeling of being close with their idol.

A growing number of scholars are concerned with the role that celebrities play in the lives of their admirers [4], and are attempting to define working vocabulary for how to talk about both celebrities and those who follow their careers (i.e., fans) with whatever relationships there might be among these individuals. Various authors have proposed different ways of talking about this relationship from Horton and Wohl's (1956) Parasocial Interaction to Caughey's (1984) Imaginary Social Relationship. Each of these terms is defined as a social relationship that is one-sided on the part of the fan and based on attraction to and interest in the celebrity. The term "fan", a word derived from "fanatic", has fallen into common usage. However, the word "fan" has come to mean a range of followers of celebrities from the casual fan to the obsessive fan (Stever, 2008a).

After several exploratory studies on the subject of celebrity worship [5], proposed a measure that would identify celebrity worshipers using a variety of 5-point Likert type items. Called the Celebrity Attitude Scale (CAS), the usefulness of the scale in identifying fans who have become overly absorbed and addicted to their interest in a celebrity is apparent. However, one problem in the application of the scale is the absence of a conceptual definition for what is meant by a "celebrity worshiper." This has resulted in some confusion between the terms "fan" and "celebrity worshiper" and how these two constructs might be related to one another. Some studies discuss the two terms as if they were interchangeable [6], citing theories about fan behavior and fan communities by placing the term celebrity worship within mental health theory [3]. However, the assumption that being a fan and being a celebrity worshiper are synonymous could be fundamentally flawed. What if these are, in fact, different constructs? Another possibility could be that one designation is a subset of the other, i.e., that celebrity worshipers are a type or level of a fan at the high or obsessive end of the scale (Stever, 2008a). While "obsession" sounds a great deal like the Borderline-Pathological subscale of the CAS, many very committed fans, whose commitment to a celebrity could be perceived as "celebrity worship," also carry on normal relationships and normal, healthy and satisfying lives (Stever 2008a).

The clearest example linking these two concepts in this literature is a reference to "socializing in celebrity worshipping fan clubs" [7]. This statement implied that fan clubs are all about celebrity worship. The authors suggested that celebrity worship is a progressive scale and that even lower levels of celebrity worship could lead to borderline-pathological celebrity worship. The rationale for this conclusion is far from clear and is not backed up by data from real fan clubs, i.e., whether any fan clubs or other identifiable fan groups are made up of celebrity worshipers, particularly such that all or even most members of such groups fit these criteria. If significant numbers of fan club members do not meet the criteria on these scales as celebrity worshipers, then it would follow that the validity of the claim that fan clubs are made up of celebrity worshipers is questionable. Also, the assertion that membership in a fan club is the first step on the road to more pathological celebrity worship is unsupported by data from real fan clubs. To infer that a person is a fan based on their score on the Celebrity Attitude Scale and then to claim that all fans are celebrity worshipers because the scale says so is circular reasoning. 
[8] observed that celebrity worship implies triviality and superficiality. He pointed out that fan-celebrity relationships involve high levels of non-reciprocal emotional dependence wherein fans project positive feelings onto the celebrity. [9] also wrote about fans who have a worshipful or religious quality in their admiration for celebrities. This includes "the communal nature of devotion, the reverence toward relics, and the sense of intimacy".

[10], "Any violence committed by individuals who also happen to be fans has been explained in terms of their fandom". [11]supported his purposeful omission of psychology from his analysis of fans because of "the anger I felt at the frequent pathologizing of fans' legitimate interpretive procedure". These scholars in popular communication studies take exception to the interpretation, by both media and some psychologists, of fan interests as pathological.

[12] distinguish between the follower and the fan. Fans claim social identity with a fan group while followers (i.e., consistent watchers or listeners) do not make a similar distinction. [13] used the term "cult fan" in deference to genres that embrace that term. Because terms like "cult" and "fan" are contested, both inside of academe and outside, rigorous definitions are confusing. Also, members of BMCI felt that this is the second family that understands them, rather than their own central family.

In an effort to show the celebrity worship to Bollywood artists, the members at BMCI make a blog as way to communicate with fellow fans of Bollywood and information about the development of the latest movies or activities that will be and have been made by members of BMCI, activities are usually carried out by members of BMCI among others celebrate the birthday of the idolized artist, watching together Bollywood films, making art activities such as dance competitions India, Indian singing, social events, etc. In addition to their blogs also make membership in some social media like Facebook, Instagram, line, path, twitter, and so on, to make better communication with other members or idolize artists. Information gathered through media about the daily life of the artists, inside or outside the movies. This kind of information will make the fans feels updated and felt close with their idol. They would feel to have high selfesteem after imitating and knowing news regarding their idols [14].

Self-esteem is an active component, cognitive and evaluative not just a private matter or psychological, but also social interaction. Self-esteem is an attitude that is based on the perception of the value of a person. It is essential to distinguish self-esteem from the more general term self-concept because the two terms often are used interchangeably. Self-concept refers to the totality of cognitive beliefs that people have about themselves; it is everything that is known about the self and includes things such as name, race, likes, dislikes, beliefs, values, and appearance descriptions, such as height and weight. By contrast, self-esteem is the emotional response that people experience as they contemplate and evaluate different things about themselves. Although self-esteem is related to the self-concept, it is possible for people to believe objectively positive things (such as acknowledging skills in academics, athletics, or arts), but continue not to like themselves. Conversely, it is possible for people to like themselves and therefore hold high self-esteem, despite their lacking any objective indicators that support such positive self-views [15].

Self-esteem is a positive or negative attitude towards the individual [15]. Positive selfesteem will make a person can overcome social rejection (not accepted and are not fused) in the environment [16]. Unlike the case with negative self-esteem, it will be challenging to accept social rejection; they would do various things in order to raise their self-esteem. Negative selfesteem is one of the factors causing psychological disorders or deviant behavior [15].

Individuals who have positive self-esteem, when faced with a problem, we are likely to know of the condition, able to face social rejection, so that they can avoid excessive behavior, celebrity worship. For individuals who have negative self-esteem, when faced with a problem; he is likely 
facing difficulty to evaluate his problems, so it tends to escape from the problems encountered by following the excessive behavior of celebrity worship. This is consistent with research conducted by [17] which states that there is a negative relationship between self-esteem and celebrity worship (borderline-pathological) low self-esteem, especially if the celebrity worship level is high and vice versa. Based on the above, the researchers wanted to know "the relationship of self-esteem with celebrity worship in Bollywood Mania Club Indonesia in Jakarta".

\section{Methods}

The populations of this research are 5,000 members of Bollywood Mania Club Indonesia in Jakarta, and sample in this study was $5 \%$ of 5000 members, which is 250 members and was determined by using Yount tables. The sampling technique in this research is probability sampling. This research included in non-experimental quantitative research. This research was conducted in Jakarta, and measuring instruments in this study using a questionnaire, distributed to the samples. Within the questionnaire, there are two variables: self-esteem with celebrity worship. In the [18] variable of self-esteem, contains aspects, namely a). Feeling of being valuable, b) Feeling of Able, and c) and feeling of Being Accepted.

Scales of celebrity worship used by the author are a modified research scale belongs to [3]. The scale was developed by the Celebrity Attitude Scale (CAS) [2]. There are three aspects that describe levels of celebrity worship: social entertainment, in which individuals have the motivation to do active search to celebrities; intense personal feeling, which is individuals have intense feeling and have a need to know anything about favorite celebrities; and borderlinepathological tendency, where individuals have uncontrolled thought sand become irrational towards their favorite celebrities.

\section{Discussion}

The results showed that male subjects amounted to 135 people $(54 \%)$ and female subjects are 115 people $(46 \%)$. The members of BMCI are teenager and adult, with age ranging from 15 to 47 years of age. Most of the members in the age 24 years, which accounted for 36 persons (14.4\%), then 23 years old was 23 people $(9.2 \%)$ and in the last order was 26 years with 21 persons $(8,4 \%)$.

Table 1. Correlation Result of Self-Esteem and celebrity worship

\begin{tabular}{lccl}
\hline & $\begin{array}{c}\text { Significant } \\
(\mathrm{p})\end{array}$ & $\begin{array}{c}\text { Correlation } \\
\text { coefficients }\end{array}$ & Information \\
\hline Self-Esttem & 0.000 & -0.403 & Significant $(\mathrm{p}<0.05)$ \\
Celebrity worship & 0.000 & -0.403 & \\
\hline
\end{tabular}

The table 1 shows there is a relationship between self-esteem with celebrity worship, where the significant value of $0.000(\mathrm{p}<0.05)$. This means that self-esteem affects celebrity worship BMCI members of Bollywood. The relationship is a negative direction. If members of BMCI 
had high self-esteem, he would be able to control their emotions, able to evaluate them self, so they would be able to love their idol naturally, or it can be said that these individuals are experiencing low celebrity worship. Moreover, when members of BMCI has low self-esteem, every time they had problems, they were less able to control their emotions, less able to evaluate the situation or problems on them self, so they tend to seek comfort outside the family by loving their idol excessive or unreasonable; in other words, these individual is experiencing a high celebrity worship.

According to Vaughan and Hogg, positive self-esteem will make an individual can overcome social rejection from their environment [16]. However, it is not the same as the case with negative self-esteem individuals. Individuals will be challenging to receive social rejection if it has negative self-esteem, so they would do various things in order to raise their self-esteem. Social rejection in this research is the feeling of rejected, abandoned, feeling of inappropriate and unattractive in comparison with their peers. Social rejection can motivate an action that is self-improvement [19]. Individuals with low self-esteem will find ways to improve it. Individuals will try to improve ourselves by doing celebrity worship. Worshiping an idol made people feel more valuable. When individuals have celebrity worship, then the individual will tend to seek any information about their idols actively. Any information obtained by an individual would be a provision for him to not feel outdated by his friends and will feel much more valuable. It can raise the self-esteem of individuals who are low due to the success and experience compared to their friends [20].

According to Michener and Delamater [21], one of the factors that affect self-esteem is a social comparison. The desire of individuals to have the feeling of being able and valuable makes individuals compare themselves to others. When people see that the figures are idolized have a good image by his ideal [21], then the individual will tend to follow the idol to raise his self-esteem. This is the characteristic of individuals in choosing the idol figures for themselves.

Thus, a high level of celebrity worship will raise an individual's self-esteem, because of their point of view. This study is consistent with research [20] which states that idolize idol can improve the self-esteem of the individuals.

\section{Conclusion}

Based on the discussion above, it can be concluded that there are a relationship between self-esteem with celebrity worship on Bollywood Mania Club Indonesia members in Jakarta. This may be caused by several factors, such as lack of emotional maturity and individuals tends to see that the idolized figure has an ideal example for them, so they tend to follow the idols footsteps in order - use of the Internet results in such groups transcending national and geographical boundaries communities.

\section{References}

[1] Damayanti, 'Fenomena demam idol di kalangan remaja', 2014. [Online]. Available: http://www.medanbisnisdaily.com/ne ws/read/2014/03/30/87472/fenomena -demamidol-di-kalangan-remaja.

[2] L. E. McCutcheon, R. Lange, and J. Houran, 'Conceptualization and measurement of celebrity worship', Br. J. Psychol., vol. 93, no. 1, pp. 67-87, 2002.

[3] J. Maltby, J. Houran, R. Lange, D. Ashe, and L. E. McCutcheon, 'Thou shalt worship 
no other gods - Unless they are celebrities: The relationship between celebrity worship and religious orientation', Pers. Individ. Dif., vol. 32, no. 7, pp. 1157-1172, 2002.

[4] J. Maltby, D. C. Giles, L. Barber, and L. E. Mccutcheon, 'Intense-personal celebrity worship and body image : Evidence of a link among female adolescents', Br. J. Health Psychol., vol. 10, pp. 17-32, 2005.

[5] J. Maltby and L. E. McCutcheon, 'Correlations between Scores on Attitudes toward Celebrities and Authoritarianism', Psychol. Rep., vol. 88, no. 3_suppl, pp. 979-980, 2001.

[6] K. Haspel, 'Understanding Fans: A review of the psychological literature', Wright Institute Graduate School of Psychology, 2006.

[7] L. E. McCutcheon, J. Maltby, J. Houran, L. Day, R. Gillett, and D. D. Ashe, 'Personality and coping: A context for examining celebrity worship and mental health', Br. $J$. Psychol., vol. 95, no. 4, pp. 411-428, 2004.

[8] C. Rojek, Celebrity. London: Reaktion books, 2001.

[9] D. Giles, Media psychology. London: Erlbaum Associates, 2003.

[10] C. Sandvoss, Fans: The mirror of consumption. Malden, MA: Polity Press, 2005.

[11] N. Couldry, 'One the set of The Sopranos: "Inside" a fan's construction of nearness', in Fandom: Identities and Communities in a Mediated World, J. Gray, C. Sandvoss, and L. Harrington, Eds. New York: New York University Press, 2007.

[12] J. Tulloch and H. Jenkins, Science fiction audiences: Watching Dr. Who and Star Trek. New York: Routledge, 1995.

[13] M. Hills, Fan Cultures. New York: Routledge, 2002.

[14] N. Istikomah, 'Masuknya Kpop ke Indonesia', 2012. .

[15] T. F. Heatherton and J. Polivy, 'Development and Validation of a Scale for Measuring State Self-Esteem', J. or Personal. Soc. Psychol., vol. 60, no. 6, pp. 895-910, 1991.

[16] S. W. Sarwono, Psikologi Remaja. Jakarta: Raja Grafindo Persada, 2006.

[17] L. Kusuma and L. Yuliawati, 'Self esteem and celebrity worship on late adolescents', Psychol. J., vol. 28, pp. 202-209, 2013.

[18] S. Coopersmith, The Antecendent of Self Esteem. San Fransisco: W.H. Freemanand Company, 1967.

[19] D. G. Myer, Psikologi Sosial, 10th ed. Jakarta: Salemba Humanika, 2012.

[20] E. Frederika, M. H. Suprapto, and K. L. Tanojo, 'Hubungan Antara Harga Diri dan Konformitas Dengan Celebrity Worship Pada Remaja Di Surabaya', J. GEMA Aktual., vol. 4, no. 1, pp. 61-69, 2015.

[21] C. J. Mruk, Self-esteem research, theory, and practice: Toward a positive psychology of self-esteem, 3rd ed. New York: Springer Publishing Company, 2006. 